\title{
SUCCESS STORIES FROM PATIENT'S WITH STROKE RECURRENCE PREVENTION: A QUALITATIVE STUDY
}

\author{
Heny Suseani Pangastuti ${ }^{1 *}$, Yeni Rustina ${ }^{2}$, Sudijanto Kamso ${ }^{3}$, Ratna Sitorus ${ }^{4}$ \\ ${ }^{1}$ Gajah Mada University \\ 2, 3,4 University of Indonesia \\ Email* : heny_pangastuti@ugm.ac.id
}

\begin{abstract}
Introduction: Recurrence is an issue encountered by patients with stroke in Indonesia. Stroke recurrence might occur due to the patient's inability to perform secondary prevention, particularly the non-pharmacological one, by changing their lifestyle. Many patients with stroke are known to survive longer with no recurrence. This research aimed to explore the experience of the patient with stroke and success in stroke recurrence prevention. Methods: This was a qualitative study using a descriptive exploratory method. Eight post-stroke patients who met the inclusion criteria participated in this research. The data were collected using an in-depth interview. The data were then analyzed using Giorgi method. Results: From the data analysis, it was found these stroke patients could survive without experiencing any recurrence in a certain period of time thanks to some reasons which could be classified in four themes, namely: 1) having a good food management habit, 2) having a good physical exercise/activity habit, 3) using traditional medicine instead of conventional medicine, and 4) there are some factors influencing successful management of stroke recurrence prevention. Conclusions: Patients with stroke, have a good experience and good habits to prevent their stroke recurrence, but they still have a misperception about convention medicine. This result shows the importance of the ability to manage recurrence risk factors in post-stroke patients, to prevent them from having a recurrence. Need further research on the use of traditional medicine in a stroke patient.
\end{abstract}

Keywords: risk factor management; stroke; stroke recurrence; success story

\section{INTRODUCTION}

Any patient who once suffered from a stroke (ischemic or hemorrhagic), will encounter many neurological problems and disorders, depending on the lesion occurring on their brains (Smeltzer \& Bare, 2004). Another problem frequently experienced by stroke patients is the recurrence of the disease they once suffered. This recurrence may happen when the patients are incapable of making secondary prevention. In this case, secondary prevention can be done non-pharmacologically by changing their lifestyle (Gofir, 2009). This lifestyle change is intended to modify the risk factors, which may lead to recurrence in stroke patients.

Referring to (Orem, 2001) theory, SelfCare Deficit Theory of Nursing, this secondary prevention can be done to meet the need for Health deviation self-care requisites. Such need arises due to the patient's inability to managing or controlling their risk factors. In Orem's opinion, this patient's inability can happen due to the limitation in self-care management. Such restriction is possible as a result of limited knowledge, limitation in making decisions and performing self-care, in this case managing the stroke risk factors (Orem, 2001).

In addition to the above, whether or not a patient is successful in managing recurrence risk factors also depends on his/her perceived possible benefits and obstacles they can get from the activity they do, self-efficacy, and attitude related to that activity (Pender, 1996). Interpersonal and situational influences also play a significant role in the success or failure of this recurrence risk factor management.

Among those patients who experienced recurrence, some can be found to survive without undergoing recurrence for an extended period. Their success maybe because they have been capable of performing self-care and fulfilling their need for health deviation selfcare requisites in managing the risk factors they have (Orem, 2001). The success story of stroke recurrence factor management performed by patients to survive without recurrence in a long period is an interesting phenomenon to explore. 
Based on the review of literature carried out by the researcher, no articles discussing the ability and success of stroke patients in preventing recurrence and managing the risk factors they have. The availability of these data could help develop a program to improve stroke patients' independence in managing recurrence risk factors. This research aimed to explore the experience of the patient with stroke and success in stroke recurrence prevention.

\section{METHODS}

It was qualitative research, with a descriptive exploratory method. The participants were those stroke patients selected using a purposive sampling method. The inclusion criteria: (1) suffering from a stroke in 2009 or 2010 based on the medical record data in one of a large hospital in Yogyakarta, Indonesia and having no recurrence for at least the last five years, (2) living in Yogyakarta, (3) experiencing no physiological problems, (4) having Mini-Mental Status Examination (MMSE) score $\geq 21$. The participant was selected one by one, following the inclusion criteria upon the in-depth interview. Saturation was obtained in eight participants.

After receiving an ethical clearance, data collected from December 2013 to April 2014. The data were collected by recording the interview using audiotape. This in-depth interview was organized in the participant's house, as agreed upon for 60-90 minutes in each of the 1-3 visits.
The data analyzed by transcribing the interview before being analyzed using Giorgi method (Streubert, H., \& Carpenter, 1999). It consisted of several stages, namely: 1) Reading all experiences available to obtain a general picture, 2) Re-reading the available descriptions, 3) Identifying the transition units from experience, 4) Clarifying and elaborating the meanings by associating one constituent to another and in entirety, 5) Transforming the original language into a concept, 6) Integrating and synthesizing the insights obtained into the descriptive structure to obtain the experience meaning.

This study is part of research: "Improvement of self-care program for a stroke patient to menage recurrence risk factors". This has ethically approved by Faculty of Nursing University of Indonesia (No. 04/H2.F12.D/HKP.02.04/2013) and Faculty of Medicine Universitas Gadjah Mada (No. KE/FK/1001/EC).

\section{RESULTS}

There were eight participants in this study, consisting of $6(75 \%)$ men and two (25\%) women, aged 55-78 years old. Seven of these $8(87,5 \%)$ participants had no recurrence for the last five years. These participants' last educations ranged from elementary schools to graduate schools (S2). For more detail, the participants' demographic data can be seen in Table 1.

Table 1. Characteristics of Participants $(n=8)$

\begin{tabular}{|c|c|c|c|c|c|c|c|c|}
\hline $\begin{array}{c}\text { Particip } \\
\text { ant }\end{array}$ & $\begin{array}{c}\mathrm{Ag} \\
\mathrm{e}\end{array}$ & $\begin{array}{c}\mathrm{Se} \\
\mathrm{x}\end{array}$ & Education & Occupation & Income & Race & $\begin{array}{c}\text { Religi } \\
\text { on }\end{array}$ & $\begin{array}{c}\text { Marital } \\
\text { status }\end{array}$ \\
\hline P-1 & 55 & M & Bachelor & $\begin{array}{c}\text { Private } \\
\text { employee }\end{array}$ & $2,000,000$ & $\begin{array}{c}\text { Javane } \\
\text { se }\end{array}$ & $\begin{array}{l}\text { Cathol } \\
\text { ic }\end{array}$ & Married \\
\hline P-2 & 61 & M & $\begin{array}{l}\text { Graduate } \\
\text { School }\end{array}$ & Civil servant & $\begin{array}{l}\text { Refuse to } \\
\text { answer }\end{array}$ & $\begin{array}{c}\text { Baline } \\
\text { se }\end{array}$ & $\begin{array}{l}\text { Hindui } \\
\text { sm }\end{array}$ & Married \\
\hline P-3 & 54 & M & $\begin{array}{c}\text { Elementary } \\
\text { School }\end{array}$ & Labor & 400,000 & $\begin{array}{c}\text { Javane } \\
\text { se }\end{array}$ & Islam & Married \\
\hline P-4 & 64 & M & $\begin{array}{l}\text { Elementary } \\
\text { School }\end{array}$ & $\begin{array}{l}\text { Agriculture } \\
\text { labor }\end{array}$ & 500,000 & $\begin{array}{c}\text { Javane } \\
\text { se }\end{array}$ & Islam & Married \\
\hline
\end{tabular}


Jurnal INJEC Vol. 4 No. 2 December 2019: 168-175

$\begin{array}{ccccccccc}\text { P-5 } & 78 & \text { M } & \begin{array}{c}\text { Elementary } \\ \text { School }\end{array} & \text { Farmer } & \text { 500,000 } & \text { Javane } & \text { Christi } & \text { Married } \\ \text { P-6 } & 69 & \text { F } & \begin{array}{c}\text { Junior High } \\ \text { School }\end{array} & \text { Housewife } & \text { Non } & \begin{array}{c}\text { Javane } \\ \text { se }\end{array} & \text { Islam } & \text { Widow } \\ \text { P-7 } & 69 & \text { F } & \begin{array}{c}\text { Junior High } \\ \text { School }\end{array} & \text { Traders } & \begin{array}{c}\text { Refuse to } \\ \text { answer }\end{array} & \begin{array}{c}\text { Javane } \\ \text { se }\end{array} & \text { Islam } & \text { Married } \\ \text { P-8 } & 59 & \text { M } & \begin{array}{c}\text { Senior High } \\ \text { School }\end{array} & \text { Retired } & 3,200,000 & \text { Batak } & \begin{array}{c}\text { Christi } \\ \text { an }\end{array} & \text { Married } \\ & & & & & & & & \end{array}$

In addition to demographic and health status data, the researcher also asked the participants to identify the recurrence risk factors they had. All participants had more than one risk factors (2-4 risk factors). Most participants had hypertension as them the risk factor (50\%), 1 participant had diabetes Mellitus as his/her risk factor. Only 1 participant stated he/she did not do physical activities, 2 participants had hypercholesterolemia as their the risk factors and 2 participants still had smoking habit even until recently.

From the analysis of data from the indepth interviews with 8 participants, four themes raised. This theme analysis can be seen in Table 2.

Table 2. Statements, sub-themes and themes

\begin{tabular}{|c|c|c|}
\hline Theme & Sub-theme & Finding \\
\hline $\begin{array}{l}\text { Having a good food } \\
\text { management habit }\end{array}$ & & $\begin{array}{l}\text { "The meal is ordinary, only reducing } \\
\text { this, salt..." (P1) } \\
\text { "not something sweet, of course" (P4) } \\
\text { "meats are prohibited..." (P4) } \\
\text { "vegetables every single day..." (P7) } \\
\text { "Ordinary, it's fruits that I eat every } \\
\text { day" (P2) }\end{array}$ \\
\hline $\begin{array}{l}\text { having a good physical } \\
\text { exercise/activity habit }\end{array}$ & & $\begin{array}{l}\text { "Ever since I recovered from a stroke, } \\
\text { I walk every morning...."(P3) } \\
\text { "of course every day I do move, } \\
\text { whatever it is, going to park, painting, } \\
\text { or to the workshop, wash the car, } \\
\text { something like that, most importantly I } \\
\text { move,...." (P2) } \\
\text { "herding ducks usually until thirty past } \\
\text { seven...from thirty past five, then, I go } \\
\text { to the field.. until 10...." (P5) }\end{array}$ \\
\hline $\begin{array}{l}\text { using traditional medicine } \\
\text { instead of conventional } \\
\text { medicine }\end{array}$ & & $\begin{array}{l}\text { "cucumber, chayote,... shredded.... } \\
\text { drink the juice.... the tension gets } \\
\text { better immediately" (P4) } \\
\text { "...these drug it is not good enough. } \\
\text {...I stopped...only juice with herbs" } \\
(P 7)\end{array}$ \\
\hline & Family support & "Well, the family help me a lot" (P8) \\
\hline
\end{tabular}




\begin{tabular}{|c|c|c|}
\hline \multirow{4}{*}{$\begin{array}{lr}\text { Factors } & \text { influencing } \\
\text { successful management of } \\
\text { stroke } \quad \text { recurrence } \\
\text { prevention }\end{array}$} & & $\begin{array}{l}\text { "ee..looks after or take care by my } \\
\text { wife." }(P 2)\end{array}$ \\
\hline & Religious influence & $\begin{array}{l}\text { "well, no... I know what liquor is, } \\
\text { whoever drinks liquor, they will be } \\
\text { prevented from smelling the heaven's } \\
\text { fragrance)" (P4) } \\
\text { "in religious beliefs. Encourage } \\
\text { maybe, so I can live a long life. "(P2) }\end{array}$ \\
\hline & $\begin{array}{l}\text { Believing and benefiting in } \\
\text { self-management }\end{array}$ & $\begin{array}{l}\text { "I only, my belief gets better.." (P3) } \\
\text { "In terms of of.. change, well it's only, } \\
\text { after suffering from stroke, I quit } \\
\text { smoking..... then the body seems } \\
\text { fresher, it's because since I had the } \\
\text { stroke, I never smoked.. Yes, so the } \\
\text { vibe.. what's it.. the air I inhale seems } \\
\text { just fresh, cool.... (P3) }\end{array}$ \\
\hline & Positive thinking & $\begin{array}{l}\text { "I don't care about the recurrence..... } \\
\text { What I care about is for it to not } \\
\text { recur." (P2) } \\
\text { "you can't force yourself" (P4) }\end{array}$ \\
\hline
\end{tabular}

\section{DISCUSSIONS}

This research tried to explore the success story, which led a Participant could survive, not experiencing stroke recurrence for more or less five years. This prevention of recurrence from occurring was an activity which could be done by stroke patients who were still recovering and rehabilitating during the patients' remaining life (Intercollegiate Stroke Working Party \& Physicians, 2012). This was classified as secondary prevention, which could be done both pharmacologically and non-pharmacologically. The activity that patient do is known as risk factor management.

The risk factor management that the participants had done to minimize this recurrence risk showed the self-care agency ability that these patients had. (Orem, 2001)defined self-care agency as an adult's sophisticated ability to be aware of and fulfil their needs and to take deliberate actions aiming at allowing the body to function and develop as desired. The management of risk factors in stroke patients can be done by changing their lifestyle such as stopping smoking, healthy diet practice, bodyweight control and regular physical activities (WHO, 2001).

Poor diet management was one of the risk factors to trigger stroke, thus managing diet well would be one of those factors which could be done to prevent the stroke recurrence. While nearly all participants said they did not practice any particular diet, in general, they applied food restrictions, such as fatty foods (meat, fried foods), reduction of salt (for those with hypertension) and sugar (for those with Diabetes Mellitus). From the 4 participants who suffered from hypertension, 3 said that they reduced the amount of salt in their meals. This 
habit would lower their blood pressure and eventually lessened the risk for stroke to occur (He \& Macgregor, 2003, in (Brinsden, H.C. \& Farrand, 2012; Sukartini et al., 2020).

Another thing which could support the participant's successful management of recurrence risk factors was because nearly all participants kept on consuming vegetables every day. The same applied to fruit consumption. While the frequency is not as often as the vegetable, some participants consumed fruits every day. Hu, Wang, Zhang, $\& \mathrm{Qu}$ (2014) found that those who ate fruits and vegetables had $21 \%$ lower possibility of suffering from a stroke. The stroke risk decreased $32 \%$ for every 200 gram per day from people who ate fruits, and $11 \%$ for every 200 gram of vegetables. This was consistent with the result of a systematic review carried out by Sherzai, Boothby, \& Sherzai (2012) who found that fruits, vegetables and nuts showed a preventive effect on stroke. In this research, the researcher did not ask in further detail quantitatively the amount of fruits and vegetables the participants usually consumed, thus to what extent this effect of consuming fruits and vegetables was on the participant's recurrence risk stroke reduction could not be ensured.

Another good habit that the participants did which also supported the successful management of stroke recurrence risk factors was reducing the consumption of oily/fatty and fried foods. Two participants revealed that they no longer ate meat or reduced their meat consumption. This was as what PERDOSSI (cit. Hartanto, 2009) recommended for (stroke) patients to reduce their use of high saturated fat foods and lessened their trans fatty acids intake such as cakes, crackers, eggs, fried foods and butter. It was highly recommended that the fat people used was from vegetables, fish, pea fruits, and nuts. (Judd et al., 2013) conducted a study to the United States population and found that those who had a Southern diet pattern, which was identical with consuming in large amount meats, fried foods, eggs, butter and sweet foods, were associated with $39 \%$ increase of stroke risk.

From the interview with the 8 participants, it could be seen that almost all participants did physical activities or exercises. Increasing physical activities was recommended to reduce the risk for stroke to occur. Physical activities had been proven capable of improving blood circulation, reducing bad blood cholesterol level, reducing weight, and lowering blood pressure. Physical activities of aerobic nature had been tested, lowering stroke risks. Exercises were also proven lowering blood pressure by $4-9 \mathrm{mmHg}$ (Pinzon, R. \& Asanti, 2010).

The duration of physical activities or exercises that the participants did was varied, ranging from 15 minutes to 1 hour, at a frequency of 2 times a week or only when they wanted to do it —what these participants did had not matched the CDC and The National Institute of Health's recommendations, i.e. regular exercises (30 minutes with moderate exercise intensity each day) as a part of a health lifestyle. However, some participants were farmers who did physical activities for hours every single day. While these could not be classified as exercises, their physical activities had exceeded (Kusuma, Y., Venketasubramanian, N., Kiemas, L.S. \& Misbach, 2009)ed what the CDC and The National Institute of Health recommended.

From the analysis of in-depth interviews with the 8 participants, a theme of preferring the use of traditional medicine or alternative to medical one was founded according to WHO's report (2002) cit. Debas et al., (2006) alternative drugs were used by $40 \%$ of the population and $70 \%$ of people in rural areas. This finding was also consistent with Kusuma, Y., Venketasubramanian, N., Kiemas, L.S. \& Misbach (2009) who conducted a survey in Indonesia and found that many stroke patients used alternative medicines. These alternative medicines that the participants used included Propolis, Soma and massage. In addition to alternative medicines, some participants were also found using traditional 
medicine or herbs, such as cucumber and chayote to lower their blood pressure, carrot juice and insulin leaves as a substitute of insulin.

National Stroke Foundation (2010) stated no clear evidence had been obtained of the use of traditional herbs from Chine nor acupuncture. Hence they were not recommended as a therapy for stroke. In line with this, van der Riet S.; \& Srithong, K., (2011) study to 6 stroke patients who used the complementary therapy of Thai massage and herbs found that the patients' physical condition did not get better as the researcher thought would.

In this research, the participants used the traditional or alternative medicines to substitute the medication prescribed by their doctor. Such use of alternative medications was merely the participant's initiative, due to their concern of chemical medicine's effect. One participant (P7) said that he/she stopped taking medications and replaced them with juice and herbs since he/she thought those medicines had an effect which was not too good to his/her body. This was not consistent with Rodriguez (2012), who suggested that neither alternative therapy nor traditional medicines could replace conventional drugs for stroke patients. However, its simultaneous use with conventional medicines might give benefit to the stroke recovery process. This needed to be seriously emphasized for stroke patients since many patients were unaware of this fact. On the other hand, such use of traditional medicines also showed that these participants lacked knowledge of the benefits of medicines for stroke patients. This proved a self-care deficit in participants who needed a nurse's intervention to allow them to develop their selfcare agency.

These factors included family support, religious influence, belief to manage recurrence risk factors, experiencing the benefits after managing risk factors, and positive thinking. The spiritual significance was experienced by participants embracing Hinduism and Islam. Religious influence was felt by the participants mainly through prayer. With prayer, (P2) thought it could encourage him/her and let him believe that he/she could live longer and recover (P6). Another experience was consuming alcohol, as revealed by (P4), who was a Muslim. His/her religion's teaching prohibited the use of alcohol. Hence all Muslim participants had no this consuming alcohol habit. Skolarus (2012) research found that the high spirituality in Mexican American ethnic played a significant role in the primary and secondary preventive attempts they did. Based on Johnstone, Franklin, Yoon, Burris, \& Shigaki (2008) research, it was found that high spiritual believe would help stroke patients have a good coping to their diseases for it allowed them to have good mental health. However, this religious or spiritual factor had nothing to do with patients' physical health.

The participant's successful or failer management of the stroke risk factors they had was also significantly influenced by selfefficacy (Pender, 1996). Self-efficacy was defined by Bandura (in Pender, 1996) as an assessment of one's ability to organize and take real actions. Self-efficacy encouraged risk factor management behaviour directly with a belief on expectation and indirectly by influencing perception towards obstacles and commitment in performing the action plan. From the interview results, it could be seen that 3 participants had strong self-efficacy to be able to manage the risk factors they had. Other participants had not been identified in terms of the self-efficacy they had. Jones, Mandy and Partridge (2009) suggested that interventions using Self-Management book containing the principles of self-efficacy could improve the patient's self-efficacy. Based on the systematic review conducted by Jones \& Riazi (2011) it was found that research on self-efficacy in stroke patients which had been held in relation to the quality of life, perceived health status, depression, daily activities and physical functions, no research had been found to study self-efficacy of stroke patients in managing the recurrence risk factors they had. 
Pender (1996) mentioned that if an individual had tasted the benefits of an action, then it would support this individual to repeat the actions they had done. In this research, the participants felt the benefits of one of risk factor management they made, i.e. by quitting smoking. P3 and P4 suggested convenient and fresh feelings after quitting smoking. This feeling was an intrinsic benefit (Pender, 1996) experienced by the participants, which led the participants to continue to practice the quit smoking decision. This intrinsic benefit then would strengthen the decision to continue to quit smoking.

Some participants had positive/optimistic thinking. This significantly supported the recovery process. Positive thinking was one of the methods of coping which could be used by stroke patients to adapt to their conditions. The result of research conducted by Kim, Park, Peterson (2011) in 6044 adults in the United States which was followed for two years, showed that an individual's high optimism was associated with the low stroke risks. This was possible since those with high confidence could perform their healthy living activities. Thus it minimized the health risk incidence and improved their wellbeing. Skolarus (2012) research also showed the more significant the optimism, the more likely it would contribute to stroke patient's improvement in Mexican America female of Mexican America.

The limitation in this research was the fact that the data were collected using an indepth interview, the researchers failed to measure the amount of vegetables and fruits quantitatively and to what extent each respondent restricted the foods they consume each day. The same also applied to the quantity and quality of physical exercises/activities performed by the participants.

\section{CONCLUSIONS}

The stroke patients' experience in managing the stroke recurrence risk factors they had was done by having a good food management habit, reasonable physical exercise/activity habit, preferring to use complementary medicine to a medical one, and the existence of factors influencing the management of risk factors. The finding obtained in this research could help nurses to understand the importance of the ability to manage recurrence risk factors in post-stroke patients to prevent them from having a recurrence. This understanding would be the basis for nurses to provide intervention in the form of health education or to make a program to better equip the patients in managing the risk factors they experienced. Many factors also influenced the ability to manage stroke recurrence risk factors. Therefore, it was highly significant for nurses to take these factors into account while treating stroke patients, to allow the optimization of the ability to manage recurrence risk factors.

\section{REFERENCES}

Brinsden, H.C. \& Farrand, C. E. (2012). Reducing salt; preventing stroke. Nutrition Bulletin, 37, 57-63.

Debas, H. T., Laxminarayan, R., \& Straus, S. E. (2006). Complementary and Alternative Medicine. Disease Control Priorities in Developing Countries, 1281-1291.

Gofir, A. (2009). Manajemen stroke: Evidence based medicine. Pustaka Cendekia Press.

Hartanto, O. S. (2009). Pencegahan primer stroke iskemik dengan mengendalikan faktor risiko. Disampaikan pada Sidang Senat terbuka UNS, 14 Desember 2009.

Hu J.; Wang, Y.; Zhang, D.; \& Qu, Y., D. . H. (2014). Fruits and vegetables consumption and risk of stroke: A metaanalysis of prospective cohort studies. . Stroke, 45, 0.

Intercollegiate Stroke Working Party, \& Physicians, R. C. of. (2012). National clinical guideline for stroke (Issue 86016_314).

Johnstone, B.,Franklin, K.L., Yoon, D.P., Burris, J. \& Shigaki, C. (2008). Relationship among religiousness, 
spirituality and health for individuals with stroke. J Clin Psychol Med Settings, 15, 308-313.

Jones, F., \& Riazi, A. (2011). Self-efficacy and self management after stroke: a sytematic review. Disability and Rehabilitation, 33(10), 797-810.

Judd, S. E., Gutiérrez, O. M., Newby, P. K., Howard, G., Howard, V. J., Locher, J. L., Kissela, B. M., \& Shikany, J. M. (2013). Dietary patterns are associated with incident stroke and contribute to excess risk of stroke in black americans. Stroke, 44 , 3305-3311. https://doi.org/10.1161/STROKEAHA.1 13.002636

Kim, E.S., Park, N., Peterson, C. (2011). Dispositional optimism protects older adults from stroke. Stroke, 42, 28552859.

Kusuma, Y., Venketasubramanian, N., Kiemas, L.S. \& Misbach, J. (2009). Burden of stroke in Indonesia. International Journal of Stroke, 4(5), 379-380.

National Stroke Foundation. (2010). Clinical guidelines for stroke management.

Orem, D. E. (2001). Nursing: Concepts of practice. Mosby.

Pender, N. . (1996). Health Promotion in Nursing Practice. Appleton \& Lange A. Simon \& Schuster Company.

Pinzon, R. \& Asanti, L. (2010). Awas Stroke: Pengertian, Gejala, Tindakan, Perawatan, dan Pencegahan. ANDI.

Rodriguez, D. (2012). Alternative therapies for stroke treatment. Diakses pada tanggal 11
September 2015.

Sherzai L.T.; Boothby, C; \& Sherzai, A.D., A. . H. (2012). Stroke, food groups, and dietary patterns: a systematic review. Nutrition Reviews, 70(8), 423-435.

Skolarus, L. E., et al. (2012). ). The Prevalence of Spirituality, Optimism, Depression, and Fatalism in a Bi-ethnic Stroke Population. J Relig Health, 51, 12931305.

Smeltzer, S. C. ., \& Bare, B. G. (2004). Smeltzer, S.C.; Bare, B. G (9th ed.). WB Saunders Company.

Streubert, H., \& Carpenter, D. (1999). Qualitative Research in Nursing: Advancing the Humanistic Perspective (2nd ed.). Lippincott Williams \& Wilkins.

Sukartini, T., Theresia Dee, T. M., Probowati, R., \& Arifin, H. (2020). Behaviour model for diabetic ulcer prevention. Journal of Diabetes \& Metabolic Disorders. https://doi.org/10.1007/s40200-01900484-1

van der Riet S.; \& Srithong, K., P. . D. (2011). complementary therapies in rehabilitation: stroke patient's narratives. Part 2. Journal of Clinical Nursing, 21, 668-676. https://doi.org/doi: 10.1111/j.1365-2702.2011.03726.x

WHO. (2001). Secondary prevention of communicable diseases in low- and middle- incomes countries through community based and health services intervention. Repport of WHO-wellcome trust meeting of Experts. 